\title{
The Sperm Structure and Spermatogenesis of Trypophloeus klimeschi (Coleoptera: Curculionidae: Scolytinae)
}

\author{
Jing Gao ${ }^{1}$, Guanqun Gao ${ }^{2}$, Jiaxing Wang ${ }^{1}$ and Hui Chen ${ }^{1,3, *(D)}$ \\ 1 College of Forestry, Northwest A\&F University, Yangling 712100, China; sxllgaojing@nwafu.edu.cn (J.G.); \\ wjx2017@nwafu.edu.cn (J.W.) \\ 2 Information Institute, Tianjin Academy of Agricultural Sciences, Tianjin 300192, China; ggqun@nwafu.edu.cn \\ 3 State Key Laboratory for Conservation and Utilization of Subtropical Agro-Bioresources, \\ Guangdong Key Laboratory for Innovative Development and Utilization of Forest Plant Germplasm, \\ College of Forestry and Landscape Architecture, South China Agricultural University, \\ Guangzhou 510642, China \\ * Correspondence: chenhui@nwsuaf.edu.cn; Tel.: +86-29-8708-2083
}

check for updates

Citation: Gao, J.; Gao, G.; Wang, J.; Chen, $\mathrm{H}$. The Sperm Structure and Spermatogenesis of Trypophloeus klimeschi (Coleoptera: Curculionidae: Scolytinae). Biology 2021, 10, 583. https://doi.org/10.3390/biology 10070583

Academic Editor: Qi Chen

Received: 29 May 2021

Accepted: 23 June 2021

Published: 25 June 2021

Publisher's Note: MDPI stays neutral with regard to jurisdictional claims in published maps and institutional affiliations.

Copyright: (c) 2021 by the authors. Licensee MDPI, Basel, Switzerland. This article is an open access article distributed under the terms and conditions of the Creative Commons Attribution (CC BY) license (https:// creativecommons.org/licenses/by/ $4.0 /$ )
Simple Summary: In the mating, reproduction, and phylogenetic reconstruction of various insect taxa, the morphological characteristics of the male reproductive system, spermatogenesis, and sperm ultrastructure are important. We investigated these morphological characteristics of Trypophloeus klimeschi (Coleoptera: Curculionidae: Scolytinae), which is one of the most destructive pests of Populus alba var. pyramidalis (Bunge) using light microscopy, scanning electron microscopy, and transmission electron microscopy. We also compared these morphological characteristics with that found in other Curculionidae.

Abstract: The male reproductive system, sperm structure, and spermatogenesis of Trypophloeus klimeschi (Coleoptera: Curculionidae: Scolytinae), which is one of the most destructive pests of Populus alba var. pyramidalis (Bunge), were investigated using light microscopy, scanning electron microscopy, and transmission electron microscopy. The male reproductive system of T. klimeschi is composed of testes, seminal vesicles, tubular accessory glands, multilobulated accessory glands, vasa deferentia, and a common ejaculatory duct. In spermatogenesis, two phenomena are apparent: The nuclear chromatin condenses into two different patterns, and an oval preacrosomal vesicle is present at the flank of the Golgi apparatus. The sperm are short, measuring $76.7 \pm 1.8 \mu \mathrm{m}$ in length, and are $508.1 \pm 12.9 \mathrm{~nm}$ in width. The sperm are composed of a three-layer acrosomal complex, a cylindrical nucleus, two mitochondrial derivatives, a $9+9+2$ axoneme, and two accessory bodies with a large "puff"-like expansion. Mature sperm are individually stored in seminal vesicles. During spermiogenesis, the similarities in the nuclear chromatin condensation characteristics of Curculioninae and Scolytinae are indicative of their close phylogenetic relationship. It appears that the preacrosomal vesicle being flanked by the Golgi apparatus is a characteristic of spermatogenesis in Curculionidae.

Keywords: male reproductive system; sperm ultrastructure; spermatogenesis; Trypophloeus klimeschi (Coleoptera: Curculionidae: Scolytinae)

\section{Introduction}

Curculionidae, with about 48,000 valid species, is the largest family of known organisms [1]. Many pest species, such as Scolytus scheoyrewi, Scolytus seulensis, Scolytus rugulosus, Scolytus multistriatus, Trypophloeus populi, Lepyrus japonicuse, Sympiezomias velatus, and Cryptorhynchus lapathi, attack poplar trees and other hardwood, causing significant economic and ecological problems worldwide [2-6]

Trypophloeus klimeschi, belonging to Scolytinae, Curculionidae [7], is one of the most destructive pests of Populus alba var. pyramidalis (Bunge). It was first recorded in the Kyrgyz Republic, which borders Xinjiang Uygur Autonomous Region in China [7-9]. Following an 
outbreak in the Dunhuang in recent years [2,10-12], this beetle has caused huge economic and ecological losses. T. klimeschi first invades branch shoots and then gradually spreads to the main trunk. The beetle bores and feeds in the phloem to form a gallery in which the eggs are deposited. The injured branches turn yellow and wither, and dense holes are formed in the trunk surface, causing the injured trees to wither and rapidly die [2]. The prevention and control of T. klimeschi must involve the control of population number [13]. Reproductive ability is one of the important factors that affect population number. Longterm field investigation has shown that $T$. klimeschi is a monogamous insect and mates once before laying eggs, and the number of eggs laid is as high as 30 [2]. Such a strong reproductive ability is the basis for its rapid spread. In order to better understand its mating and reproduction, morphological information of the male reproductive system, the sperm structure, and spermiogenesis is essential [14].

The morphological characteristics of the male reproductive system, spermatogenesis, and sperm ultrastructure have been considered important in taxonomy of various insect taxa [15-23]. The Scolytinae subfamily includes 6000 species belonging to 200 genera [24], and more studies of these areas are needed for its phylogenetic reconstruction considering the huge number of species. Only a few species of these areas have been studied, such as Dendroctonus rnonticolae, Hypothenemus hampei, Dendroctonus armandi, and Hylurgus ligniperda [13,25-28]. The male reproductive tract of most Scolytinae is composed of testes, seminal vesicles, accessory glands, vasa deferentia, and ejaculatory duct $[13,25-28]$ Their sperm usually contain a nucleus, a $9+9+2$ axoneme, two accessory bodies, two mitochondrial derivatives, and one "puff"-like expansion [13,19]. However, there seem to be exceptions among these species. For example, Hypothenemus hampei has no accessory glands [26], and the sperm of $D$. armandi also contains a special large spongy body [13]. Although these studies revealed important information regarding the phylogenetic reconstruction of Scolytinae, these structures may vary significantly, even between closely related species [18]. There is still an urgent need for more research on the male reproductive system, sperm, and spermatogenesis of this subfamily.

Due to the wide variety and rapid spread of bark beetles, the lack of phylogenetic studies may lead to untimely identification and inadequate proliferation detection of their species. At present, only adult integument morphology, larval morphology, antenna receptor morphology, and life history can provide support for the systematic status of T. klimeschi $[2,8,9]$. Ning et al. predicts that $T$. klimeschi will quickly spread to more places in the future [29]. Therefore, the aim of this research was to study the reproductive system, spermatogenesis, and sperm ultrastructure of T. klimeschi using light microscopy, scanning electron microscopy, and transmission electron microscopy. This study provides key information for future research into mating, reproduction, and the systematic status of T. klimeschi, more evidence for phylogenetic reconstruction of Scolytinae, and potentially useful information for subsequent pest control.

\section{Materials and Methods}

\subsection{Insects}

T. klimeschi (larvae and pupae) collected from the bark of infested P. alba var. pyramidalis in Dunhuang City $\left(40^{\circ} 06^{\prime} 50.61^{\prime \prime}\right.$ N, $94^{\circ} 36^{\prime} 10.24^{\prime \prime}$ E), Gansu Province, China, were reared in 24-hole plates with feed containing $P$. alba var. pyramidalis bark powder in an artificial climate incubator (14L: 10D, $25 \pm 1{ }^{\circ} \mathrm{C}, 65 \pm 5 \%$ relative humidity) [2]. On the 1st, 8 th, and 16th day after eclosion, 30 males were taken for later use in experiments. For anatomical analyses, the reproductive systems of 30 males-10 T. klimeschi each at 1,8 , and 16 days after eclosion-were observed with an OLYMPUS SZ2-ILST stereomicroscope and photographed with an OLYMPUS DP25 camera.

\subsection{Scanning Electron Microscopy (SEM)}

The reproductive systems of the 10 males in each age group were dissected and fixed in a solution containing $2.5 \%$ glutaraldehyde in $0.1 \mathrm{M}$ phosphate ( $\mathrm{pH} 7.2)$ for $12 \mathrm{~h}$ at $4{ }^{\circ} \mathrm{C}$ [2]. 
The samples were washed in phosphate-buffered saline (PBS), pH 7.2; dehydrated through a graded series of alcohol and isoamyl acetate; critical point dried with liquid $\mathrm{CO}_{2}$; and sputter coated with gold. Samples were then examined using a HITACHI S-4800 scanning electron microscope at $15 \mathrm{kV}$.

\subsection{Transmission Electron Microscopy (TEM)}

The 10 fixed samples of reproductive systems for each age group were rinsed with PBS, and post-fixation was performed in $1 \%$ osmium tetroxide for $1 \mathrm{~h}$ at $4{ }^{\circ} \mathrm{C}$. After four 15 min washes in the same buffer, the samples were dehydrated through a graded ethanol series and embedded in 14381-UC LR WHITE. Semithin sections were obtained with a glass knife on a LEICA RM2265 microtome, stained with toluidine blue, and observed with an OLYMPUS BX43F microscope. Ultrathin sections (70 $\mathrm{nm}$ thick) were obtained with a diamond knife on an ultramicrotome (LEICA ULTRACUT UCT), routinely stained with uranyl acetate and lead citrate, and observed with a HITACHI HT7700 transmission electron microscope.

\section{Results}

\subsection{Gross Morphology of the Male Reproductive System}

From the light microscopy images, we observed that the male internal reproductive tract of T. klimeschi is composed of two units (Figure 1A). Each unit comprises a bilobed testis-a seminal vesicle inserted in the depression of the testis- two accessory glands (multilobulated gland and tubular gland), and the vas deferens (Figure 1A). The tubular accessory gland is connected to the seminal vesicle, while the multilobulated accessory gland surrounds the vas deferens (Figure 1A). Two units fuse at their posterior ends, flowing into an ejaculatory duct (Figure 1A). On the first day after eclosion, the seminal vesicles are only thin tubules (Figure 1B), which become thicker with maturation (Figure 1A).

The cysts were observed to completely fill the testes (Figure 1C). A cyst is a saccular structure composed of cyst cells (Figure 2A), within which spermatogenesis occurs. During spermatogenesis, spermatogonia undergo repeated mitotic divisions and give rise to spermatocytes. These spermatocytes undergo successive meiotic divisions and give rise to spermatids, which, after morphological change (spermiogenesis), form spermatozoa. In each cyst, 350-512 ( $\mathrm{n}=10)$ spermatozoa were observed, resulting from nine cell division cycles. Mature sperm were observed to fill the seminal vesicles.

\subsection{Spermatogenesis}

\subsubsection{From Spermatogonia to Spermatids}

Transmission electron microscopy allowed us to determine that the spermatogonia are irregularly shaped cells (Figure 2A,B, Table S1), $5.6 \pm 0.4 \mu \mathrm{m}(\mathrm{n}=10)$ in diameter, with a large, irregularly shaped nucleus $(3.5 \pm 0.7 \mu \mathrm{m}, \mathrm{n}=10)$. The nucleus contains homogeneously distributed granular chromatin and irregularly distributed electron-dense heterochromatin (Figure 2A,B). The cytoplasm contains many mitochondria and large lysosomes (Figure 2B).

The spermatocytes (Figure 2C, Table S1) originate from mitosis of spermatogonia and have a diameter of $4.8 \pm 0.3 \mu \mathrm{m}(\mathrm{n}=10)$. The cells are characterized by synaptonemal complexes in the round nucleus $3.1 \pm 0.4 \mu \mathrm{m}(\mathrm{n}=10)$ in diameter (Figure 2D, Table S1). Lysosomes, mitochondria with well-defined cristae, Golgi apparatus (Figure 2C), and two orthogonally arranged centrioles (Figure 2E) can be observed in the cytoplasm.

The spermatids (Figure 2F, Table S1) contain a round nucleus $2.1 \pm 0.3 \mu \mathrm{m}(\mathrm{n}=10)$ in diameter. Nuclear chromatin exhibits different degrees of compactness and electron density. This stage is characterized by the presence of fusing mitochondria (Figure 2F). 


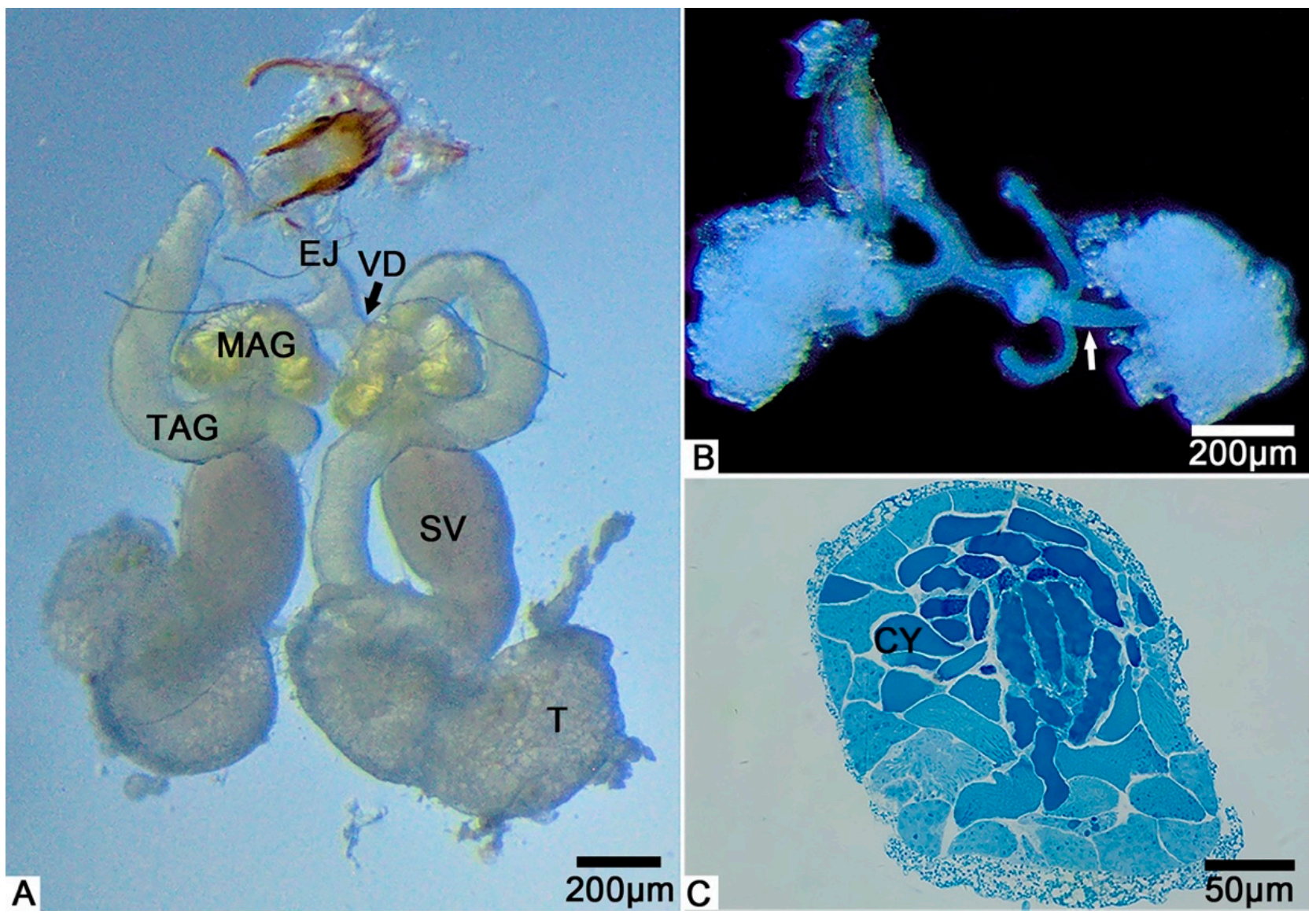

Figure 1. The male reproductive system of T. klimeschi: (A) The male reproductive system on the 16th day after eclosion. (B) On the first day after eclosion, the seminal vesicles are only thin tubules (white arrow). (C) The cross section of the testis showing many cysts (CY). Testis (T); seminal vesicle (SV); tubular accessory gland (TAG); multilobulated accessory gland (MAG); vas deferens (VD); ejaculatory duct (EJ).

\subsubsection{Spermiogenesis}

Germ cells undergo many changes during spermiogenesis: The nuclear chromatin becomes more concentrated, and the electron density is enhanced (Figure 3A,B). The lateroposterior end of the nucleus forms a concavity where the basal body is located, and the axoneme elongates from here (Figure $3 \mathrm{~A}, \mathrm{~B})$. A round preacrosomal vesicle, $448.3 \pm 14.5 \mathrm{~nm}$ $(\mathrm{n}=10)$ (Table S1) in diameter, is visible (Figure 3C). At the initial stage of spermatid differentiation, the preacrosomal vesicle is near the nebenkern and Golgi apparatus (Figure 3C). In the early spermatid, when the nebenkern becomes two mitochondrial derivatives, the preacrosomal vesicle is found near the Golgi apparatus (Figure 3D) and nucleus (Figure 3E). In more detail, the preacrosomal vesicle flanks and is near to the concave face of the Golgi apparatus (Figure 3D). In this stage, the preacrosomal vesicle has a dark-stained mantle and a light core (Figure 3E); both are surrounded by a membrane (Figure 3F). As the cell elongates, the preacrosomal vesicle flattens (Figure 3G). At a more mature stage, the bell-shaped nucleus is obvious, and its nuclear chromatin shows two distinct regions (Figure 3H): one homogeneously compact, the other fibrillar. At this stage of development, all sperm components are surrounded by microtubules (Figure $3 \mathrm{H}$ ). Shortly after this, the centriolar adjunct is visible on both sides of the basal body (Figure 3I). However, there are no centriolar adjuncts in the mature sperm. 


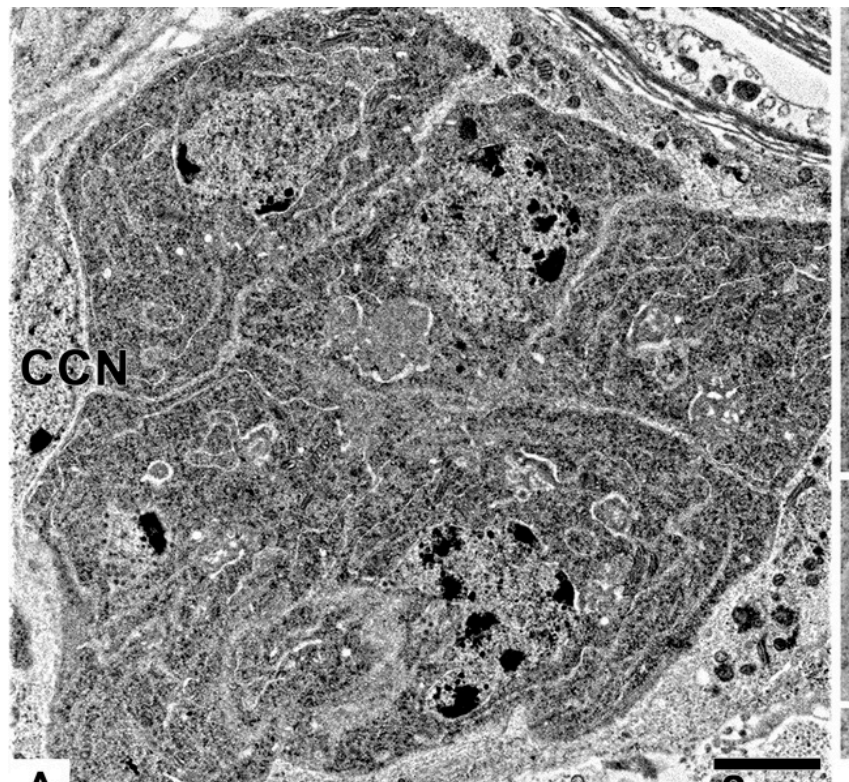

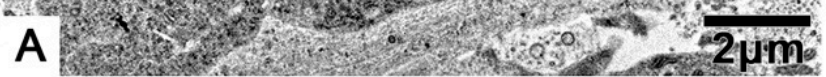
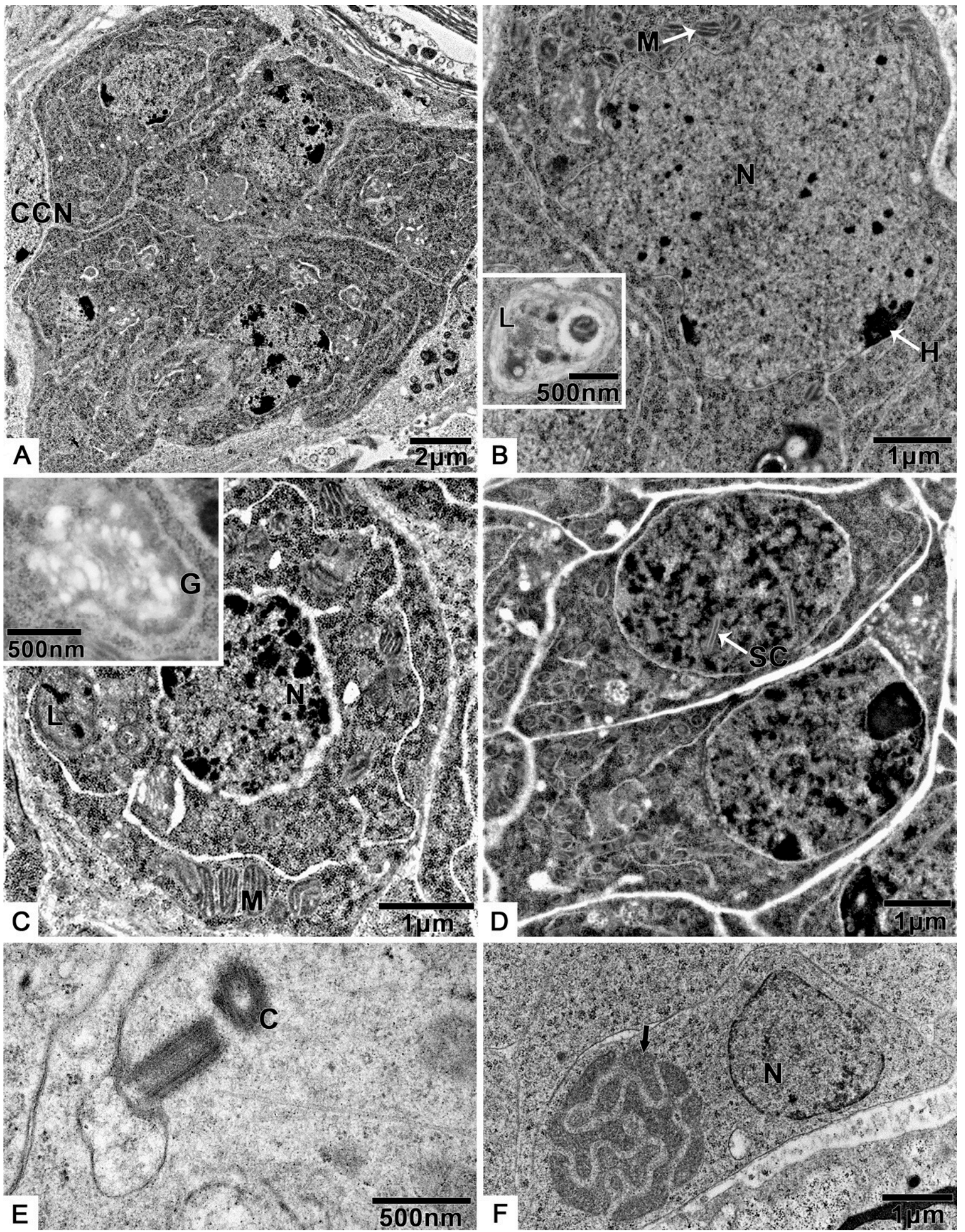

Figure 2. The spermatogenesis of T. klimeschi: (A) spermatogonia cyst; (B) spermatogonia; (C) primary spermatocytes; (D) secondary spermatocytes; (E) centrioles in spermatocytes; $(\mathbf{F})$ spermatids. Cyst cell nucleus $(\mathrm{CCN})$; centrioles $(\mathrm{C})$; heterochromatin $(\mathrm{H})$; mitochondria $(\mathrm{M})$; Golgi apparatus $(\mathrm{G})$; lysosomes $(\mathrm{L})$; nucleus $(\mathrm{N})$; synaptonemal complexes (SC); fusing mitochondria (black arrow). 

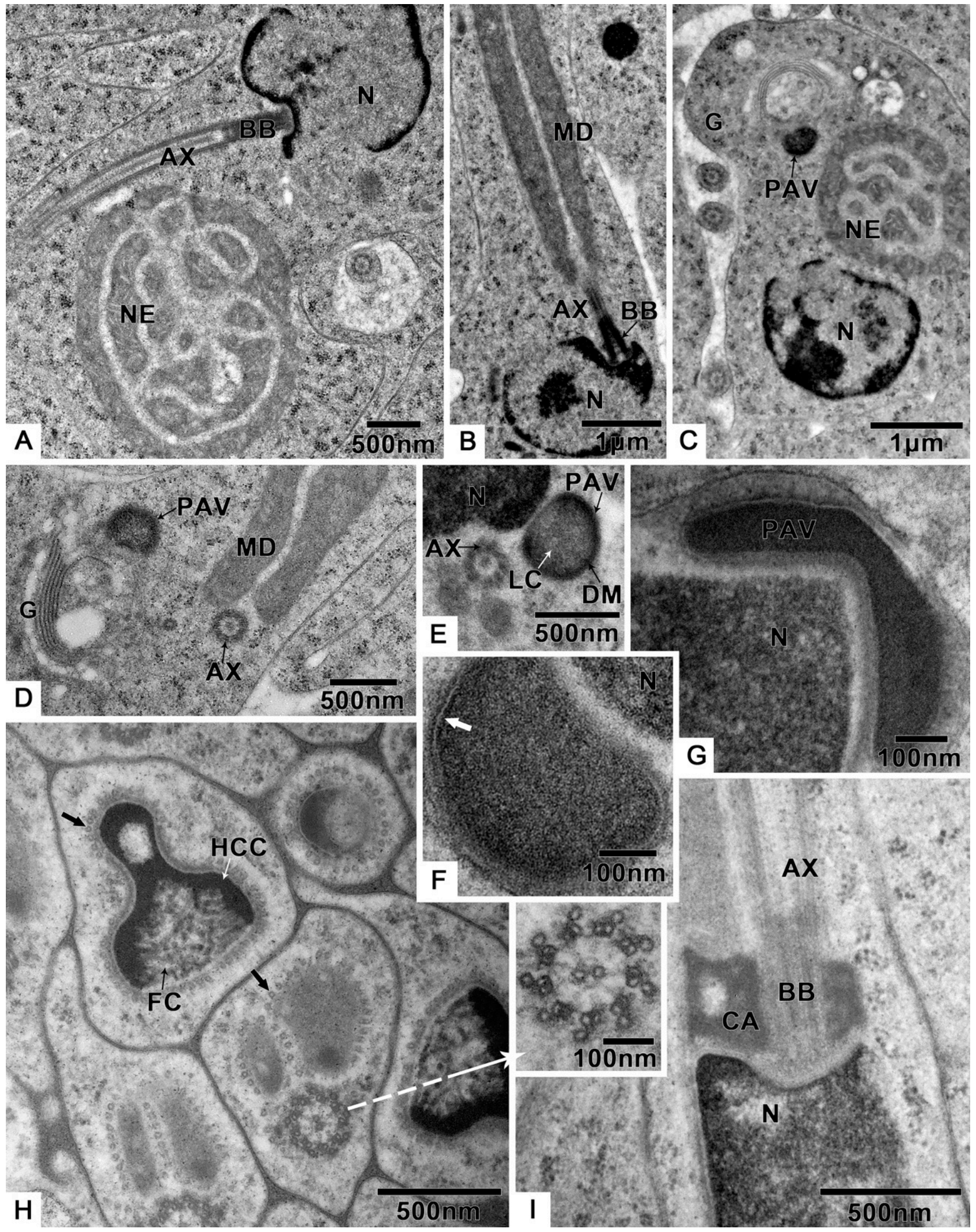

Figure 3. Spermiogenesis of T. klimeschi: (A) The axoneme starts elongating from the concavity of nucleus. (B) Mitochondrial derivatives are located on both sides of the axoneme and parallel to the axoneme. (C) Spermatid at initial stage of differentiation showing that the preacrosomal vesicle is near to the nebenkern and Golgi apparatus. (D,E) In the early spermatid (nebenkern becomes two mitochondrial derivatives), the preacrosomal vesicle and axoneme are near to the Golgi apparatus (D) and nucleus (E). The preacrosomal vesicle has a dark-stained mantle and light core (E). (F) The preacrosomal 
vesicle under high magnification and its membrane structure (white arrow). (G) As the nucleus elongates, the preacrosomal vesicle becomes flat. (H) The spermatid components are surrounded by microtubules (black arrow). The bell-shaped nucleus with different chromatin aggregation states: homogeneously compact chromatin and fibrillar chromatin. The cross section of the axoneme under high magnification (white arrow). (I) The centriolar adjunct appears in the spermatid stage. Nucleus (N); axoneme (AX); preacrosomal vesicle (PAV); nebenkern (NE); Golgi apparatus (G); dark-stained mantle (DM); light core (LC); homogeneously compact chromatin (HCC); fibrillar chromatin (FC); mitochondrial derivatives (MD); centriolar adjunct (CA); basal body (BB).

During spermiogenesis, the spherical-shaped mitochondria, which are found dispersed in the cytoplasm, begin to gather (Figure 4A). Then, the formation of two mitochondrial derivatives begins via stages that are twinned (Figure 4B), five-layer (Figure $4 \mathrm{C}$ ) and two-layer nebenkern (Figure 4D,E). These two mitochondrial derivatives become slender (Figure $4 \mathrm{~F}$ ) as the spermatid and axoneme elongate (Figure 3B).

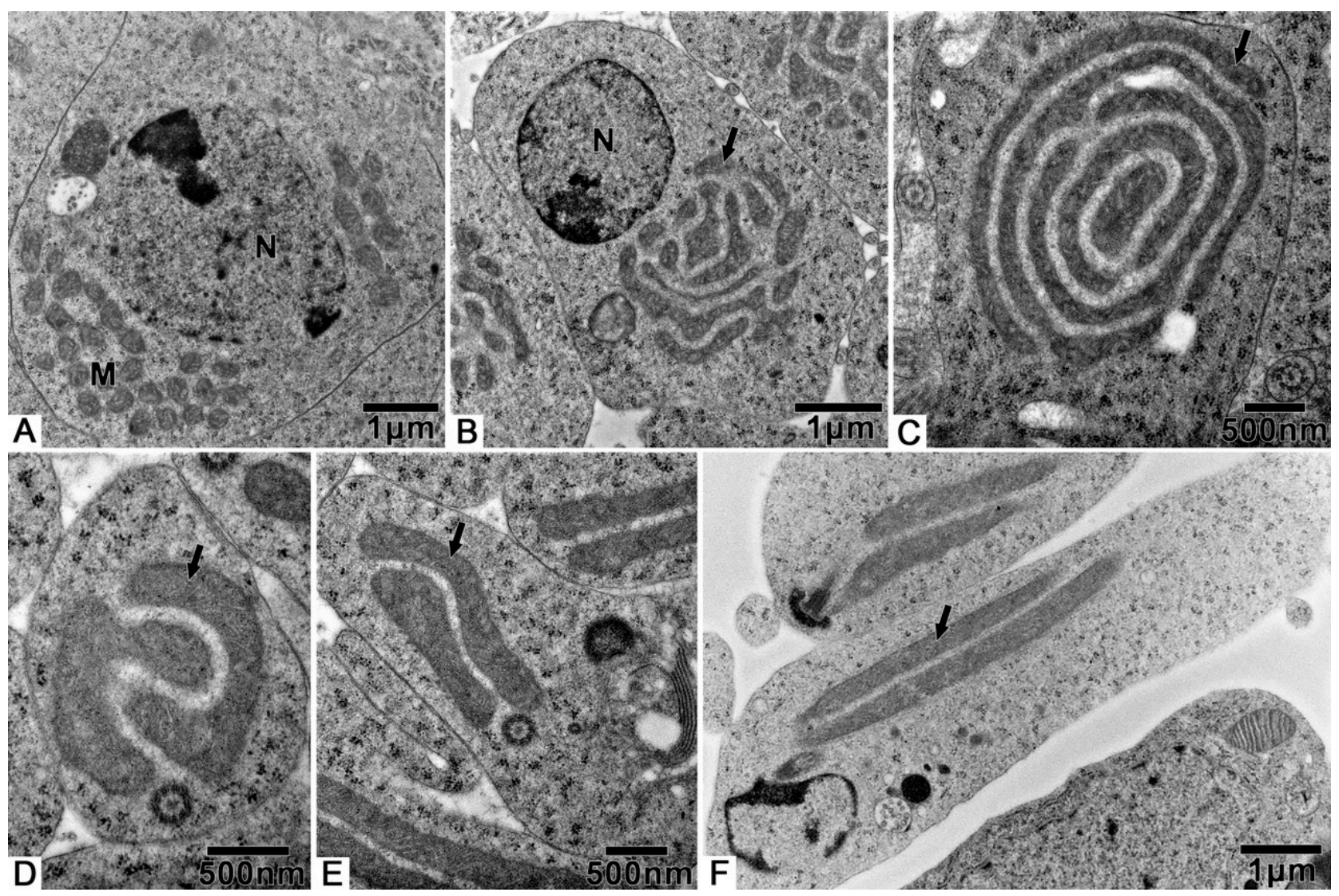

Figure 4. Changes of mitochondria during spermiogenesis of T. klimeschi: (A) Mitochondria (M) gathered together; (B-F) changing mitochondria (black arrow). Nucleus (N).

\subsection{Spermatozoa}

The spermatozoa of T. klimeschi are slender (Figure 5A, Table S1), measuring $76.7 \pm 1.8 \mu \mathrm{m}$ $(\mathrm{n}=10)$ in length and $508.1 \pm 13.0 \mathrm{~nm}(\mathrm{n}=10)$ in width, and composed of an acrosomal complex, a nucleus (Figure 6A), an axoneme, two mitochondrial derivatives, and two accessory bodies (Figure 6F). The mitochondrial derivatives do not embrace the axoneme but rather run approximately parallel to it (Figure 5B). Mature sperm are stored in the seminal vesicles and its cross section, showing that the sperm of T. klimeschi are arranged very closely on the 16th day after eclosion (Figure 5C). 

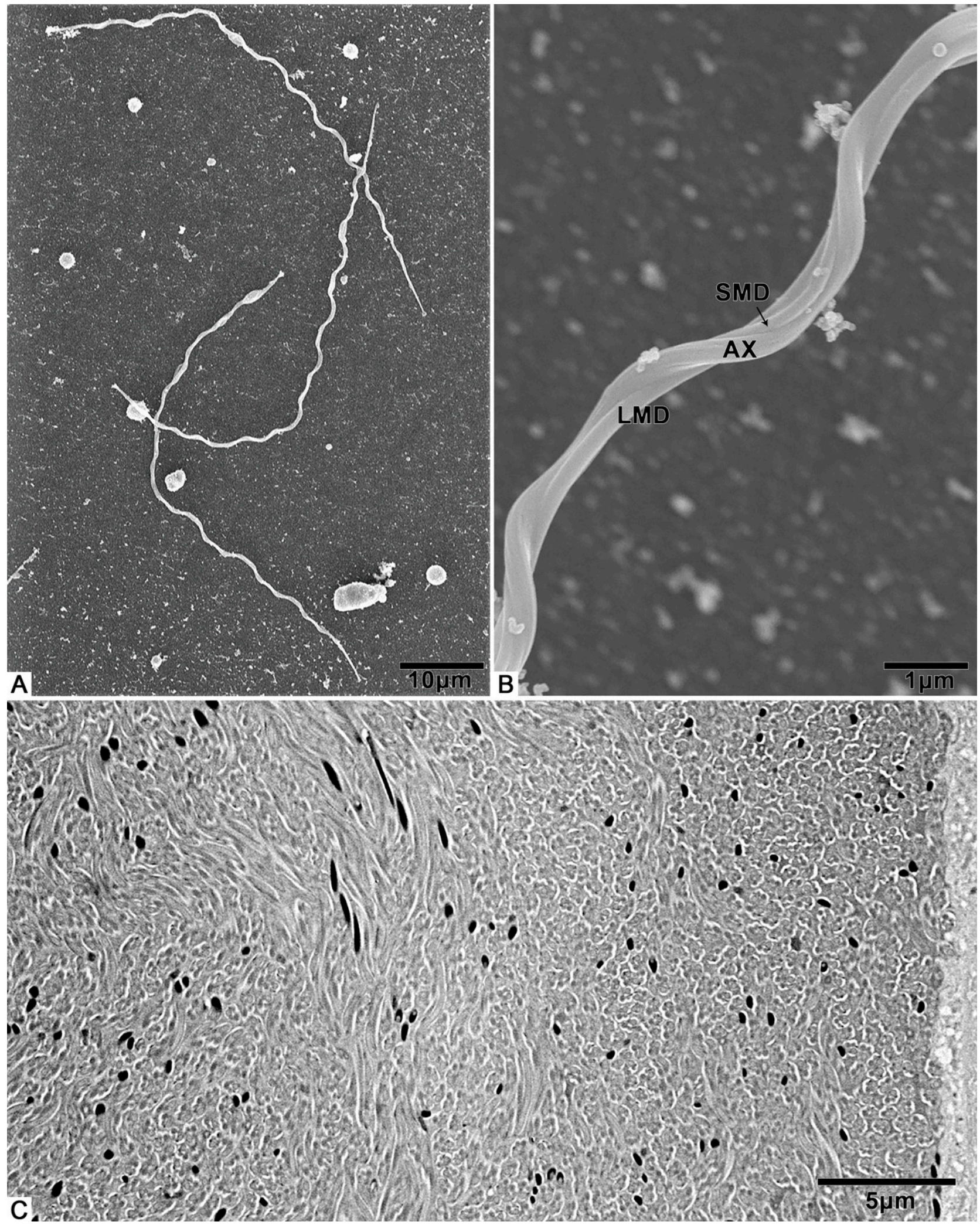

Figure 5. SEM and TEM micrographs of T. klimeschi spermatozoa: (A) The appearance of spermatozoa; (B) Detailed view of spermatozoa; (C) TEM micrograph of spermatozoa in seminal vesicles. The black, round, and short strips are the sperm nuclei. Axoneme (AX); large mitochondrial derivative (LMD); small mitochondrial derivative (SMD). 

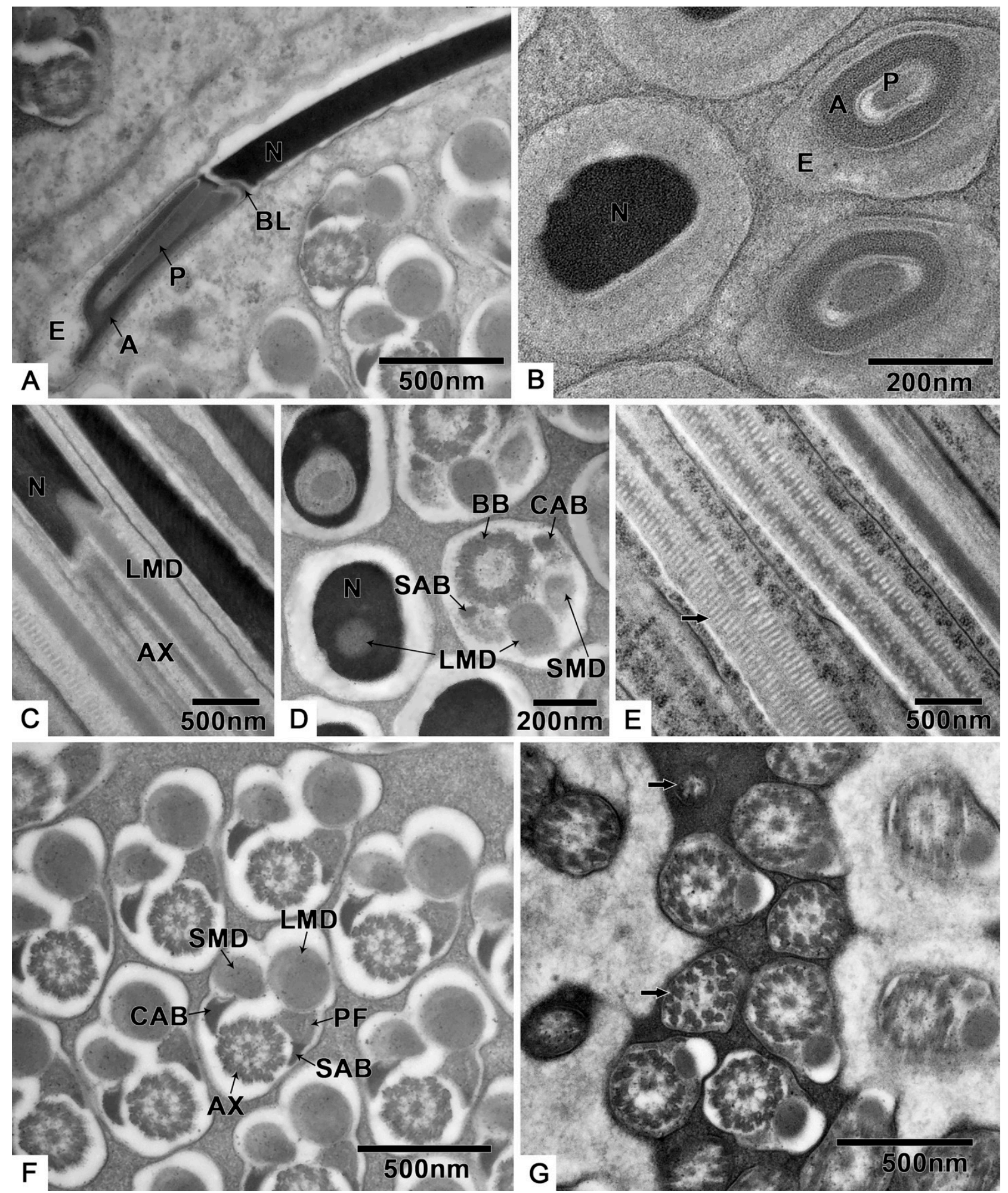

Figure 6. The spermatozoa structure of T. klimeschi: (A,B) The longitudinal and cross sections of 3-layered acrosome complex. (C,D) The longitudinal and cross sections showing the junction of the nucleus and flagellar components. (E) The mitochondrial cristae (black arrow). (F) Cross section of the middle of the spermatozoa. (G) Cross section showing the disorganized axoneme (black arrow) at the end of the spermatozoa. Extra acrosomal layer (E); acrosomal vesicle (A); perforatorium (P); nucleus (N); basal lamina (BL); axoneme (AX); large mitochondrial derivative (LMD); small mitochondrial derivative (SMD); crescent accessory body (CAB); basal body (BB); small accessory body (SAB); puff-like expansion (PF). 
The three-layer acrosomal complex (Figure 6A,B, Table S1), measuring $1.2 \pm 0.0 \mu \mathrm{m}$ $(n=10)$ in length, is made up of a dense extra acrosomal granular layer, a cup-like acrosomal vesicle, and a rod-like conical perforatorium. The acrosomal complex lies on a slightly concave nuclear face and is separated from the nucleus by a thick basal lamina (Figure 6A).

The nucleus is close to the acrosomal complex (Figure 6A,B) with a circular cross section, which is indicated by a longitudinal section that is $6.0 \pm 0.2 \mu \mathrm{m}(\mathrm{n}=10)$ in length and $289.9 \pm 22.6 \mathrm{~nm}(\mathrm{n}=10)$ in diameter (Table S1).

The longitudinal and cross sections (Figure 6C,D) show that the flagella components are inserted into the nucleus, while the large mitochondrial derivative is the deepest. The $9+9+2$ axoneme (Figure 6F, Table S1) has a diameter of $282.9 \pm 8.1 \mathrm{~nm}(\mathrm{n}=10)$. The large mitochondrial derivative with distinct cristae (Figure 6E), $236.0 \pm 18.9 \mathrm{~nm}(\mathrm{n}=10)$ in diameter is always thinner than the axoneme and becomes thinner along the flagellum before completely disappearing (Figure 6G).

The two accessory bodies are different in shape (Figure 6F). From the cross section of the middle part of the sperm, we know that the crescent accessory body is smaller than one-quarter of the axoneme size, and the other is small and mostly triangular (sometimes crescent-shaped) with a large, compact, "puff"-like expansion.

At the end of the sperm, the two accessory bodies are the first to disappear, followed by the smaller mitochondrial derivative, larger mitochondrial derivative, and, finally, the disorganized disappearance of the axoneme (Figure 6G).

\section{Discussion}

In terms of general morphology, the male reproductive tract of T. klimeschi is composed of two testes, two seminal vesicles, two tubular accessory glands, two multilobulated accessory glands, two vasa deferentia, and an ejaculatory duct, and this composition is identical to that reported for other Curculionidae [13,25-27,30-32].

T. klimeschi has two types of accessory gland. The multilobulated accessory glands of some Scolytinae-for instance, D. armandi [13], Scolytus destructor [28], H. ligniperda [27], and D. rnonticolae [25] — correspond to the prostate glands of some species of other Curculionidae subfamilies, such as Hyperodes bonariensis (Coleoptera: Curculionidae: Cylindrorhininae) [31], Listronotus bonariensis (Coleoptera: Curculionidae: Cylindrorhininae) [33], and Tanymecus dilaticollis (Coleoptera: Curculionidae: Entiminae) [32]. Because the two structures have a similar appearance (they are both circular and multilobulated) and position (they are both next to tubular accessory glands and surround vasa deferentia), it is possible that they have the same structure. However, H. hampei (Coleoptera: Curculionidae: Scolytinae) [26] does not have this accessory gland.

In T. klimeschi, spermatogenesis occurs in cysts, as is the case for most insects [34-38]. The number of sperm per cyst is less than 512 as a result of nine cycles $\left(2^{9}\right)$ of cell division. In Coleoptera, the number of divisions is between 4 to 10 [13,21,34,39]. According to the hypothesis of Virkki [40], insects of more archaic orders have more sperm cells per bundle than their more modern counterparts; if so, T. klimeschi may be a primitive coleopteran species.

It seems that two different patterns of nuclear chromatin condensation during spermiogenesis (one showing the chromatin more homogeneously condensed and another showing the chromatin with a fibrillar aspect) is a shared feature of Curculionidae [13,21,30,34,41]. However, the process of condensation is different and can generally be divided into two types: one having a honeycomb chromatin stage, such as for Sitophilus zeamais (Coleoptera: Curculionidae: Dryophthorinae), Sitophilus oryzae (Coleoptera: Curculionidae: Dryophthorinae) [21], and Rhynchophorus ferrugineus (Coleoptera: Curculionidae: Rhynchophorinae) [41], and the other not, such as for Anthonomus grandis (Coleoptera: Curculionidae: Curculioninae) [30], and D. armandi [13]. T. klimeschi belongs to the latter. In addition, another feature of the latter is its bell-shaped nucleus [13,34]. This result supports the theory that there is a close relationship between Curculioninae and Scolytinae, and Rhynchophorinae and Dryophthorinae [19,42]. 
In insects, as in animals in general, the acrosome is a product of the Golgi apparatus [43]. The position of the acrosome changes as the sperm matures. However, in the early spermatid, for many insects, the preacrosomal vesicle is situated on the concave face of the Golgi apparatus, between its innermost cisternae and the spermatid nucleus, such as in Euschistus (Hemiptera: Pentatomidae) [43], some Orthoptera [44], Acheta domesticus (Orthopteroidea, Ensifera) [45], Sciara coprophila (Diptera, Sciaridae) [46,47], and Machilontus sp. (Archaeognatha: Meinertellidae) [48]. However, in Conocephalus (Orthoptera: Tettigoniidae) [43], the preacrosomal vesicle is situated on the convex side of the Golgi apparatus, which is situated between the preacrosomal vesicle and the nucleus. In this study, the preacrosomal vesicle is situated on the flank of the Golgi apparatus and near to the concave face of the Golgi apparatus. The preacrosomal vesicle was also found in the same position in some Curculionidae, for example, S. oryzae [21] and R. ferrugineus [49]. However, unlike the bean-shaped preacrosomal vesicle of $S$. oryzae and the round preacrosomal vesicle of $R$. ferrugineus, the vesicle of T. klimeschi is oval-shaped. This special position of the preacrosomal vesicle may be a characteristic of Curculionidae.

The spermatozoa of T. klimeschi are linear and slender and are similar to the general description for other Curculionidae sperm [13,21,30,50]. Compared to spermatozoa of other Curculionidae, which are 110 to $300 \mu \mathrm{m}$ in length [19], they are short, with a length of about $77 \mu \mathrm{m}$, though they share a similar structure to most $[13,19,21,22,30,50,51]$ : a three-layer acrosome with a cup-like acrosome vesicle; a $9+9+2$ axoneme; two mitochondrial derivatives of different sizes; a large mitochondrial derivative, which is always thinner than the axoneme in, for example, D. armandi [13], Kissophagus hederae (Coleoptera: Curculionidae: Scolytinae), and Ernoporus fagi (Coleoptera: Curculionidae: Scolytinae) [19]; two accessory bodies; and one large, compact, "puff"-like expansion.

At present, two types of insect spermatozoa storage have been characterized: in bundles and individually [18,52-55]. Bundled spermatozoa are maintained in primary arrangement (the arrangement in the testes), and their heads are inserted into the extracellular matrix. However, there seems to be no description of how spermatozoa are individually stored. In this study, according to the cross section of the seminal vesicle of T. klimeschi (Figure 5C), we determined that the sperm are arranged very tightly, but the sperm heads are not always gathered together as is the case for the heads of sperm stored in bundles [55]. Instead, the sperm heads are dispersed similarly to when they are stored individually [53]. Therefore, based on this observation, we believe that the sperm of T. klimeschi are individually stored in seminal vesicles.

\section{Conclusions}

In conclusion, the general morphology of the male reproductive tract, spermatogenesis, and the structure of the spermatozoa of T. klimeschi is, for the most part, similar to that of the majority of the Scolytinae. However, the spermatozoa of T. klimeschi is, at approximately $77 \mu \mathrm{m}$, very short. During spermiogenesis, the similarity in the nuclear chromatin condensation characteristics of Scolytinae and Curculioninae is indicative of their close phylogenetic relationship. The preacrosomal vesicle flanking the Golgi apparatus seems to be a characteristic of spermatogenesis in Curculionidae. This study provides novel information on the reproductive biology of the Curculionidae family and develops the existing taxonomic and phylogenetic research on Curculionidae.

Supplementary Materials: The following are available online at https:/ /www.mdpi.com/article/10 $.3390 /$ biology10070583/s1. Table S1: Size of different cells and organelles.

Author Contributions: Conceptualization, J.G.; methodology, J.G. and G.G.; software, J.W.; formal analysis, J.G.; investigation, J.G., J.W. and G.G.; writing—original draft preparation, J.G.; writingreview and editing, J.W.; supervision, H.C.; funding acquisition, H.C. All authors have read and agreed to the published version of the manuscript.

Funding: This work was funded by the National Natural Science Foundation of China (31870636) and the National Key Research and Development Program of China (2017YFD0600104-4). 
Institutional Review Board Statement: Not applicable.

Informed Consent Statement: Not applicable.

Data Availability Statement: Not applicable.

Conflicts of Interest: The authors declare no conflict of interest.

\section{References}

1. Anderson, R.S. Weevils and plants: Phylogenetic versus ecological mediation of evolution of host plant associations in curculioninae (coleoptera: Curculionidae). Memoirs Èntomol. Soc. Can. 1993, 125, 197-232. [CrossRef]

2. Gao, G. Occurrence and Host Selection Mechanism of Trypophloeus klimeschi Eggers. Ph.D. Thesis, Northwest A\&F University, Yangling, China, 2018.

3. Marchetti, S.B.; Worrall, J.J.; Eager, T. Secondary insects and diseases contribute to sudden aspen decline in southwestern Colorado, USA. Can. J. For. Res. 2011, 41, 2315-2325. [CrossRef]

4. Legalov, A.A. Revised checklist of weevils (Coleoptera: Curculionoidea excluding Scolytidae and Platypodidae) from Siberia and the Russian Far East. Acta Biol. Sib. 2020, 6, 437-549. [CrossRef]

5. Cave, G.L.; Redlin, S.C. Importation of Chinese Penjing into the United States with Particular Reference to Ehretia microphylla; United States Department of Agriculture: Riverdale, MD, USA, 1996.

6. Broberg, C.L.; Borden, J.H.; Humble, L.M. Distribution and abundance of Cryptorhynchus lapathi on Salix spp. in British Columbia. Can. J. For. Res. 2002, 32, 561-568. [CrossRef]

7. Eggers, V.O.H. Trypophloeus klimeschi nov. spec. Entomol. Bl. 1915, 25, 7-9.

8. Cao, Y.; Luo, Z.; Wang, S.; Zhang, P. Trypophloeus klimeschi Eggers-A new insect pest to Xinjiang poplar. J. Tarim Univ. 2003, 15, 9-11.

9. Cao, Y.; Luo, Z.; Wang, S.; Zhang, P. Bionomics and control of Trypophloeus klimeschi. Entomol. Knowl. 2004, 41, 36-38.

10. Gao, G.; Dai, L.; Gao, J.; Wang, J.; Chen, H. Volatile Organic Compound Analysis of Host and Non-Host Poplars for Trypophloeus klimeschi (Coleoptera: Curculionidae: Ipinae). Russ. J. Plant Physiol. 2018, 65, 916-925. [CrossRef]

11. Gao, G.; Gao, J.; Hao, C.; Dai, L.; Chen, H. Biodiversity and Activity of Gut Fungal Communities across the Life History of Trypophloeus klimeschi (Coleoptera: Curculionidae: Scolytinae). Int. J. Mol. Sci. 2018, 19, 2010. [CrossRef] [PubMed]

12. Gao, G.; Dai, L.; Gao, J.; Wang, J.; Chen, H. Electroantennogram, behavioural responses, and field trapping of Trypophloeus klimeschi (Coleoptera: Curculionidae: Scolytinae) to eight host volatiles. Can. Èntomol. 2019, 151, 236-250. [CrossRef]

13. Wu, Y.-F.; Wei, L.-S.; Torres, M.A.; Zhang, X.; Wu, S.-P.; Chen, H. Morphology of the Male Reproductive System and Spermiogenesis ofDendroctonus armandiTsai and Li (Coleoptera: Curculionidae: Scolytinae). J. Insect Sci. 2017, 17, 20. [CrossRef] [PubMed]

14. Oberprieler, R.G.; Marvaldi, A.E.; Anderson, R.S. Weevils, weevils, weevils everywhere. Zootaxa 2007, 1668, 491-520. [CrossRef]

15. Kuschel, G. A phylogenetic classification of Curculionoidea to families and subfamilies. Mem. Entomolol. Soc. Wash. 1995, 14, 5-33.

16. Dallai, R. Overview on spermatogenesis and sperm structure of Hexapoda. Arthropod Struct. Dev. 2014, 43, 257-290. [CrossRef]

17. Salazar, K.; Dias, G.; Boucher, S.; Lino-Neto, J.; Serrão, J.E. Morpho-anatomy of the male reproductive tract and spermatogenesis of the South American Spasalus silvarum Kuwert (Coleoptera: Passalidae). Zoomorphology 2016, 135, 487-497. [CrossRef]

18. Schubert, L.F.; Krüger, S.; Moritz, G.B.; Schubert, V. Male reproductive system and spermatogenesis of Limodromus assimilis (Paykull 1790). PLoS ONE 2017, 12, e0180492. [CrossRef] [PubMed]

19. Burrini, A.G.; Magnano, L.; Magnano, A.R.; Scala, C.; Baccetti, B. Spermatozoa and phylogeny of Curculionoidea (Coleoptera). Int. J. Insect Morphol. Embryol. 1988, 17, 1-50. [CrossRef]

20. Dallai, R.; Afzelius, B.A.; Lupetti, P.; Osella, G. Sperm structure of some Curculionoidea and their relationship with Chrysomeloidea. Boll. Mus. Regionale Sci. Nat. Torino. 1998, 1, 27-50.

21. Name, K.P.; Dos Reis, G.P.; Báo, S.N. An ultrastructural study of spermiogenesis in two species of Sitophilus (Coleoptera: Curculionidae). Biocell 2007, 31, 229-236. [CrossRef]

22. Dallai, R.; Gottardo, M.; Beutel, R.G. Structure and Evolution of Insect Sperm: New Interpretations in the Age of Phylogenomics. Annu. Rev. Èntomol. 2016, 61, 1-23. [CrossRef]

23. Dallai, R.; Mercati, D.; Fanciulli, P.P.; Petrioli, A.; Lupetti, P. New findings on the sperm ultrastructure of Carabidae (Insecta, Coleoptera). Arthropod Struct. Dev. 2020, 54, 100912. [CrossRef] [PubMed]

24. Kuschel, G.; Leschen, R.A.B.; Zimmerman, E.C. Platypodidae under scrutiny. Invertebr. Syst. 2000, 14, 771-805. [CrossRef]

25. Cerezke, H.F. The Morphology and Functions of the Reproductive Systems of Dendroctonus monticolae Hopk. (Coleoptera: Scolytidae). Can. Èntomol. 1964, 96, 477-500. [CrossRef]

26. Rubio, G.J.D.; Bustillo, P.A.E.; Vallejo, E.L.F.; Acuña, Z.J.R.; Benavides, M.P. Alimentary canal and reproductive tract of Hypothenemus hampei (Ferrari) (Coleoptera: Curculionidae, Scolytinae). Neotrop. Èntomol. 2008, 37, 143-151. [CrossRef]

27. Calder, A.A. Gross morphology of the soft parts of the male and female reproductive systems of Curculionoidea (Coleoptera). $J$. Nat. Hist. 1990, 24, 453-505. [CrossRef]

28. Aslam, N.A. An assessment of some internal characters in the higher classification of the curculionidae s.l. (coleoptera). Trans. R. Entomol. Soc. Lond. 1961, 113, 417-480. [CrossRef] 
29. Ning, H.; Tang, M.; Chen, H. Mapping Invasion Potential of the Pest from Central Asia, Trypophloeus klimeschi (Coleoptera: Curculionidae: Scolytinae), in the Shelter Forests of Northwest China. Insects 2021, 12, 242. [CrossRef] [PubMed]

30. Grodner, M.L. Aberrant spermatogenesis in hybrid progeny of sub-species of the boll weevil Anthonomus grandis Boheman (Coleoptera: Curculionidae). Int. J. Insect Morphol. Embryol. 1975, 4, 107-114. [CrossRef]

31. Goldson, S.L.; Emberson, R.M. Reproductive morphology of the Argentine stem weevil, Hyperodes bonariensis (Coleoptera: Curculionidae). N. Z. J. Zoöl. 1981, 8, 67-77. [CrossRef]

32. Koçakoğlu, N.Ö.; Candan, S.; Güllü, M. The histomorphological structure of the male reproductive system of maize leaf weevil Tanymecus dilaticollis Gyllenhal, 1834 (Coleoptera: Curculionidae). Microsc. Res. Tech. 2019, 82, 1345-1352. [CrossRef]

33. Barker, G.M. Functional anatomy of the reproductive system ofListronotus bonariensis (Kuschel). N. Z. Èntomol. 1989, 12, 34-42. [CrossRef]

34. Gassner, G.; Childress, D.; Klemetson, D.J.; Iii, G.G. Spermiogenesis in boll weevil, Anthonomus grandis Boheman (Coleoptera: Curculionidae). Int. J. Insect Morphol. Embryol. 1975, 4, 115-125. [CrossRef]

35. Gracielle, I.M.S.; Fiorillo, B.S.; Lino-Neto, J.; Báo, S.N. Morphology of the male reproductive system and spermiogenesis in Hypanthidium foveolatum (Alfken, 1930) (Hymenoptera: Apidae: Megachilinae). Micron 2009, 40, 419-425. [CrossRef] [PubMed]

36. Xie, S.; Hua, B. RETRACTED: Sperm ultrastructure in two species of Panorpa and one Bittacus (Mecoptera). Micron 2010, 41, 622-632. [CrossRef]

37. Werner, M.; Simmons, L.W. Ultrastructure of spermatozoa of Onthophagus taurus (Coleoptera, Scarabaeidae) exhibits heritable variation. Naturwissenschaften 2011, 98, 213-223. [CrossRef]

38. Dias, G.; Lino-Neto, J.; Mercati, D.; Dallai, R. The sperm ultrastructure and spermiogenesis of Tribolium castaneum (Coleoptera: Tenebrionidae) with evidence of cyst degeneration. Micron 2015, 73, 21-27. [CrossRef] [PubMed]

39. Jurecic, R. Sperm cell number per bundle in Gnorimus nobilis L. (Coleoptera, Scarabaeidae). Genetica 1988, 76, 27-31. [CrossRef]

40. Virkki, N. Sperm bundles and phylogenesis. Cell Tissue Res. 1969, 101, 13-27. [CrossRef]

41. Paoli, F.; Dallai, R.; Cristofaro, M.; Arnone, S.; Francardi, V.; Roversi, P.F. Morphology of the male reproductive system, sperm ultrastructure and $\gamma$-irradiation of the red palm weevil Rhynchophorus ferrugineus Oliv. (Coleoptera: Dryophthoridae). Tissue Cell 2014, 46, 274-285. [CrossRef]

42. Morrone, J.J.; Marvaldi, A.E. Phylogenetic systematics of weevils (Coleoptera: Curculionoidea): A reappraisal based on larval and adult morphology. Insect Syst. Evol. 2000, 31, 43-58. [CrossRef]

43. Phillips, D.M. Insect sperm: Their structure and morphogenesis. J. Cell Biol. 1970, 44, 243-277. [CrossRef] [PubMed]

44. Gatenby, J.B.; Tahmisian, T.N. Centriole adjunct, centrioles, mitochondria, and ergastoplasm in Orthopteran spermatogenesis. An electron microscope study. Cellule Rec. Trav. Originaux Cytol. Histol. Biol. Gen. 1959, 60, 105.

45. Kaye, J.S. Acrosome formation in the house cricket. J. Cell Biol. 1962, 12, 411-431. [CrossRef]

46. Phillips, D.M. Observations on spermiogenesis in the fungus gnat sciara coprophila. J. Cell Biol. 1966, 30, 477-497. [CrossRef] [PubMed]

47. Phillips, D.M. Fine structure of sciara coprophila sperm. J. Cell Biol. 1966, 30, 499-517. [CrossRef] [PubMed]

48. Fanciulli, P.P.; Mercati, D.; Machida, R.; Dallai, R. Spermiogenesis and sperm ultrastructure of Machilontus sp (Insecta: Archaeognatha) with phylogenetic consideration. Micron 2015, 73, 47-53. [CrossRef]

49. Alzahrani, A.M.; Abdelsalam, S.A.; Elmenshawy, O.M.; Abdel-Moneim, A.M. Ultrastructural Characteristics of Spermiogenesis inRhynchophorus ferrugineus (Coleoptera: Curculionidae). Fla. Ėntomol. 2013, 96, 1463-1469. [CrossRef]

50. Dallai, R.; Lino-Neto, J.; Dias, G.; Nere, P.H.A.; Mercati, D.; Lupetti, P. Fine structure of the ladybird spermatozoa (Insecta, Coleoptera, Coccinellidae). Arthropod Struct. Dev. 2018, 47, 286-298. [CrossRef]

51. Jamieson, B.G.M.; Dallai, R.; Afzelius, B.A. Insects: Their Spermatozoa and Phylogeny; Science Publishers: Enfield, CT, USA, 1999 ; p. 555.

52. Mojica, J.M.; Bruck, D.L. Sperm bundle coiling: Transporting long sperm bundles in Drosophila dunni dunni. J. Insect Physiol. 1996, 42, 303-307. [CrossRef]

53. Moreira, J.; Zama, U.; Lino-Neto, J. Release, behavior and phylogenetic significance of spermatozoa in bundles in the seminal vesicle during sexual maturation in Aculeata (Hymenoptera). Braz. J. Morphol. Sci. 2004, 21, 185-189.

54. Moreira, J.; Brito, P.; Mancini, K.; Dolder, H.; Lino-Neto, J. The descriptions of new microanatomical structures of the male reproductive system and sperm of Myschocyttarus cassununga (Hymenoptera: Vespidae). Micron 2012, 43, 292-297. [CrossRef] [PubMed]

55. Oliveira, C.M.; Moreira, J.; Gomes, L.F.; Camargo-Mathias, M.I.; Lino-Neto, J. Sperm Bundles in the Seminal Vesicle of the Crematogaster victima (Smith) Adult Males (Hymenoptera: Formicidae). Neotrop. Èntomol. 2014, 43, 201-208. [CrossRef] [PubMed] 